\title{
THE ANALYSIS OF SPECIFIC IMMUNE RESPONSE FOR BORRELIA BURGDORFERI ACCORDING TO IN VIVO ANTIGENS IN REGARD TO SYMPTOMS SUBJECTIVELY PERCEIVED BY FORESTERS
}

\author{
Małgorzata Tokarska-Rodak ${ }^{1,2}$, Maria Kozioł-Montewka ${ }^{1,2}$, Dorota Plewik ${ }^{3}$, \\ Justyna Paszkiewicz ${ }^{2}$, Adam Szepeluk³ , Anna Pańczuk²,
}

\author{
${ }^{1}$ Department of Medical Microbiology, Medical University of Lublin \\ ${ }^{2}$ Department of Health, Pope John Paul II State School of Higher Education in Biala Podlaska \\ ${ }^{3}$ Innovation Research Center, Pope John Paul II State School of Higher Education in Biala Podlaska
}

Tokarska-Rodak M., Kozioł-Montewka M., Plewik D., Paszkiewicz J., Szepeluk A., Pańczuk A. (2014) The analysis of appearing and disappearing dynamics of antibodies for borellia burgdorferi antigenic protein form in vivo group among forest service employees on the basis of two-stage studies, Health Problems of Civilization 1 (8) p. 32-38

\begin{abstract}
Summary:
The aim of our this work was analysis of specific immune response for B. burgdorferi according to in vivo antigens in regard to symptoms subjectively perceived by foresters, in 2009 and 2012.

Material and methods: study group include 41 foresters (19 - 86 years old), from the forest district in Lubelskie region. All persons underwent serological diagnostic. We used 2 phase diagnosis method of Lyme diseases according to standards. Used tests include Borrelia antigens from in vivo group, which are not use in standard diagnosis test. The study was carried out in 2009 and then again in 2012.

Results: The analysis of antibodies for Borrelia proteins, including the in vivo, demonstrated how active, long-term and time-variable is the process of $B$. burgdorferi infection.

Conclusions: The expression of Borrelia proteins and high immunogenicity translates into effectiveness of diagnostic procedures concerning $B$. burgdorferi identification. Considering to not clear clinical manifestation and changeable immune response require individual approach to each patient.
\end{abstract}

Keywords: Borrelia burgdorferi, in vivo antigens, Lyme disease

\section{Introduction}

Borrelia spirochaetes dispose of the package of proteins facilitating adjustment to: the microenvironment conditions in a specific organism, survival in those conditions, tissues colonization, and facilitate the ability to change the host. Since a considerable number of spirochaetes proteins is characterized by high immunogenicity, they are also significant from the perspective of diagnosis of Borrelia infections in humans. The most significant marker for early-stage infection are IgM antibodies directed against to OspC protein. They have significance diagnostic meaning and decreases in the period of late anti-Borrelia response. After that immunodominant role is taken over by VlsE, p30, DbpA (Aguero-Rosenfeld et al., 2005, Aberer 2007, EUCALB 2008, Bárcena-Uribarri et al., 2012, Coburg et al. 2013). Incredibly significant are Borrelia burgdorferi proteins which are expressed only in mammal organisms, whereas such expression is not observed in ticks or in culture mediums. A group of this type of proteins calls 'in vivo' proteins. Together with VlsE and DbpA, also BBA36, BBO323, CRASP3, pG are included in that group (Aguero-Rosenfeld et al., 2005, Zajkowska et al., 2006, Wilske et al., 2007, Bykowski et al. 2008, EUCALB 2008, Coburg et al., 2013). BBA36 and BB0323 proteins are considered as an important marker for advanced stages of Lyme disease in IgG serology. They are detected in patients with disseminated Lyme disease and neuroborreliosis (Zajkowska et al., 2006) and with Lyme arthritis (Tokarska-Rodak et al., 2008, Tokarska-Rodak et al., 2010). Although the antigens from in vivo group are most commonly specified as distinctive for the late Lyme disease stage, researches have shown that we can find them in patients with early stage borreliosis (Zajkowska et al., 2006). The appearance and disappearance of antibodies to various antigenic proteins of Borrelia is therefore a dynamic and time-variable process. It is a matter for people occupationally exposed to tick bites. Foresters are expose to multiple tick bites, and high risk of being infected with Borrelia.

Adress for correspondence: Małgorzata Tokarska-Rodak Department of Medical Microbiology, Medical University of Lublin, Chodźki 1, 20093 Lublin, e-mail: rodak.malgorzata@gmail.com, phone +48 (81) 742-37-47 


\section{The aim of work}

The aim of our work was analysis of specific immune response for B. burgdorferi according to in vivo antigens in regard to symptoms subjectively perceived by foresters, in 2009 and 2012.

\section{Material and methods}

The study group include 41 foresters (19 to 86 years), from one forest district in Lubelskie region. The screening test Elisa (Euroimmun) has been carried among all persons from the tested group towards the presence of antibodies IgM/IgG anti-Borrelia. Among those who met positive or delimited results from screening test Elisa, another test of Western blot (Wb, Euroimmun) has been carried in order to confirm the infection. The subjects who met positive results of $\mathrm{Wb}$ (Euroimmun) test with the presence of antibodies IgM and/or IgG anti-Borrelia have been submitted to broader diagnostic tests regarding the infection with B. burgdorferi. The antibodies IgG has been detected for in vivo antigens of Borrelia burgdorferi: BBA36, BB0323, CRASP3, pG (Virotech GmbH). The study was carried out in two periods: December 2009 and then the same people again, in December 2012. Also the surveys were taken. We asked about: tick bites in 2009-2012 period, presence of erythema migrans (EM) in that period, and others symptoms which can be associated with being bitten by a tick, and antibiotic therapy. The study obtained the approval of the bioethics committee.

\section{Results}

The 32\% foresters from study group have not immune response for IgM/IgG anti-B. burgdorferi in two diagnostic periods $(2009,2012)$. During 3 years period (2009-2012) foresters noticed tick-bitten: once (10 persons) or multiple ( 3 persons). None of 13 respondents developed erythema migrans (EM) or symptoms which could be associated with tick bites (table 1).

Table 1. Results of the Western blot test aimed to detect the presence of anti-Borrelia antibodies among forest service employees - no Borrelia burgdorferi infection

\begin{tabular}{|c|c|c|c|c|c|c|c|c|}
\hline \multirow{2}{*}{$\begin{array}{c}\text { Number } \\
\text { of } \\
\text { patients }\end{array}$} & \multicolumn{4}{|c|}{2009} & \multicolumn{4}{|c|}{2012} \\
\hline & $\begin{array}{l}\text { Wb } \\
\text { IgM }\end{array}$ & $\begin{array}{l}\mathrm{Wb} \\
\operatorname{IgG}\end{array}$ & $\begin{array}{l}\text { Antigens } \\
\text { from in vivo } \\
\text { group }\end{array}$ & Symptoms & $\begin{array}{l}\text { Wb } \\
\text { IgM }\end{array}$ & $\begin{array}{l}\text { Wb } \\
\text { IgG }\end{array}$ & $\begin{array}{l}\text { Antigens } \\
\text { from in vivo } \\
\text { group }\end{array}$ & Symptoms \\
\hline $13(32 \%)$ & \multicolumn{4}{|c|}{ no Borrelia burgdorferi infection } & \multicolumn{4}{|c|}{ no Borrelia burgdorferi infection } \\
\hline
\end{tabular}

In 10\% (4 persons) in 2009 no anti-Borrelia antibodies were found. The same persons in December 2012 had positive results of IgM and IgG antibodies for Borrelia burgdorferi (table 2). The respondents this group declared symptoms like headaches, osteoarticular pains, myalgia and reported undertaking the treatment (table 2).

Table 2. Results of the Western blot test aimed to detect the presence of anti-Borrelia antibodies among forest service employees - identification of infection in a tested period

\begin{tabular}{|c|c|c|c|c|c|c|c|c|c|c|}
\hline \multirow[b]{2}{*}{$\begin{array}{l}\text { Number } \\
\text { of } \\
\text { patients }\end{array}$} & \multicolumn{5}{|c|}{2009} & \multicolumn{5}{|c|}{2012} \\
\hline & $\begin{array}{l}\text { Wb } \\
\text { IgM }\end{array}$ & $\begin{array}{l}\text { Wb } \\
\text { IgG }\end{array}$ & $\begin{array}{l}\text { Antigens } \\
\text { from in vivo } \\
\text { group }\end{array}$ & Symptoms & Treatment & $\begin{array}{l}\text { Wb } \\
\text { IgM }\end{array}$ & $\begin{array}{l}\text { Wb } \\
\text { IgG }\end{array}$ & $\begin{array}{c}\text { Antigens } \\
\text { from in vivo } \\
\text { group }\end{array}$ & Symptoms & Treatment \\
\hline $4(10 \%)$ & \multicolumn{5}{|c|}{ no Borrelia burgdorferi infection } & $\begin{array}{c}\text { OspC anty- } \\
\text { B. afzelii } \\
\text { B. garinii } \\
\text { B.burgdorferi } \\
\text { s.l. } \\
\text { B. spielmanii }\end{array}$ & + & $\begin{array}{c}\text { VlsE, } \\
\text { CRASP3, } \\
\text { BBA36 }\end{array}$ & $\begin{array}{c}\text { Headaches } \\
\text { osteoarticular } \\
\text { pinas } \\
\text { myalgia }\end{array}$ & + \\
\hline
\end{tabular}


The dynamics of appearance, maintenance and disappearance of IgM/IgG anti-Borrelia antibodies is an incredibly individual matter. In accordance with existing guidelines, presence of antibodies cannot constitute the only criteria taken into account when diagnosing Lyme disease. Clinical picture, epidemical and clinical history are significance of individual patient.

One person (2\%) declared a tick bite, and EM symptoms, and also reported undergoing the treatment in 2009, while in 2012 IgG anti-Borrelia were detected, without the presence of the symptoms (table 3).

Table 3. Results of the Western blot test aimed to detect the presence of anti-Borrelia antibodies among forest service employees - profile change of produced anti-Borrelia antibodies

\begin{tabular}{|c|c|c|c|c|c|c|c|c|c|}
\hline \multirow[b]{2}{*}{$\begin{array}{c}\text { Number } \\
\text { of } \\
\text { patients }\end{array}$} & \multicolumn{5}{|c|}{2009} & \multicolumn{4}{|c|}{2012} \\
\hline & $\begin{array}{l}\mathrm{Wb} \\
\text { IgM }\end{array}$ & $\begin{array}{l}\text { Wb } \\
\text { IgG }\end{array}$ & $\begin{array}{l}\text { Antigens } \\
\text { from in vivo } \\
\text { group }\end{array}$ & Symptoms & Treatment & $\begin{array}{l}\text { Wb } \\
\text { IgM }\end{array}$ & $\begin{array}{l}\mathrm{Wb} \\
\mathrm{IgG}\end{array}$ & $\begin{array}{l}\text { Antigens } \\
\text { from in vivo } \\
\text { group }\end{array}$ & Symptoms \\
\hline $\begin{array}{c}1 \\
(2 \%)\end{array}$ & $\begin{array}{c}\text { OspC anty- } \\
\text { B. afzelii } \\
\text { B. garinii } \\
\text { B.burgdorferi s.l. } \\
\text { B. spielmanii }\end{array}$ & - & - & EM & + & - & + & $\begin{array}{l}\text { VlsE, CRASP3, } \\
\text { BBA36, } \\
\text { BB0323, pG }\end{array}$ & $\begin{array}{c}\text { no } \\
\text { symptoms }\end{array}$ \\
\hline
\end{tabular}

The treatment used in patients in early stage of immune response to the infection can bring satisfactory results by reducing symptoms and elimination of a specific immune response directed against bacteria. However, patients after treatment can be seronegative, but clinical symptoms can stay. Situation like that hinders proper functioning and professional work, especially physical work. For many people it is also emotional problem, what is emphasized by a large number of infectious diseases physicians treating Lyme disease. The above observations confirm the examples of 4 patients (10\%) in whom, in 2009 we observed presence of IgM anti-OspC for B. afzelii, $B$. burgdorferi s.s., B. garinii i B. spielmanii. In the 2012 diagnosis period the obtained results were negative (table 4 ). All patients underwent antibiotic therapy after 2009 relating to the symptoms, but in 2 case, osteoarticular pains and myalgia were not eliminated.

Table 4. Results of the Western blot test aimed to detect the presence of anti-Borrelia antibodies among forest service employees - elimination of infection with maintenance of symptoms

\begin{tabular}{|c|c|c|c|c|c|c|c|c|c|c|}
\hline \multirow[b]{2}{*}{$\begin{array}{l}\text { Number } \\
\text { of } \\
\text { patients }\end{array}$} & \multicolumn{5}{|c|}{2009} & \multicolumn{5}{|c|}{2012} \\
\hline & $\begin{array}{l}\text { Wb } \\
\text { IgM }\end{array}$ & $\begin{array}{l}\text { Wb } \\
\text { IgG }\end{array}$ & $\begin{array}{l}\text { Antigens } \\
\text { from in } \\
\text { vivo } \\
\text { group }\end{array}$ & Symptoms & Treatment & $\begin{array}{l}\text { Number } \\
\text { of } \\
\text { patients }\end{array}$ & $\begin{array}{l}\text { Wb } \\
\text { IgM }\end{array}$ & $\begin{array}{l}\mathrm{Wb} \\
\mathrm{IgG}\end{array}$ & $\begin{array}{l}\text { Antigens } \\
\text { from in } \\
\text { vivo } \\
\text { group }\end{array}$ & Symptoms \\
\hline \multirow[t]{2}{*}{$4(10 \%)$} & \multirow{2}{*}{$\begin{array}{c}\text { OspC anti- } \\
\text { B. afzelii } \\
\text { B. garinii } \\
\text { B.burgdorferi s.l. } \\
\text { B. spielmanii }\end{array}$} & \multirow{2}{*}{ - } & \multirow{2}{*}{ - } & \multirow{2}{*}{$\begin{array}{l}\text { osteoarti- } \\
\text { cularpains, } \\
\text { myalgia }\end{array}$} & \multirow{2}{*}{+} & 2 & \multicolumn{3}{|c|}{$\begin{array}{c}\text { no anti-Borrelia } \\
\text { burgdorferi } \\
\text { antibodies }\end{array}$} & $\begin{array}{c}\text { osteoarticular } \\
\text { pinas } \\
\text { myalgia }\end{array}$ \\
\hline & & & & & & 2 & \multicolumn{3}{|c|}{$\begin{array}{c}\text { no anti-Borrelia } \\
\text { burgdorferi } \\
\text { antibodies }\end{array}$} & no symptoms \\
\hline
\end{tabular}

In 2009 one forester (2\%) had IgG anti-VlsE antibodies, and he reported osteoarticular pains and antibiotic treatment (table 5). In the test in 2012, there was no presence of anti-Borrelia antibodies in any class in his serum. Forester declared the existence of another tick bite in spring 2012, the occurrence of EM, and informed about used treatment because of EM.

His pain declared in 2009 remained and during the test in December 2012. The existence of clinical symptoms associated with Lyme disease does not exclude the occurrence of early skin manifestations (EM) after subsequent ticks bites. Antibiotics, used in accordance with the recommendations, successfully stopped the process of early new infection as evidenced by the lack of specific IgM antibodies. Despite multiple treatments, there was not satisfactory elimination of other symptoms for the patient that had existed after the first infection. 
Tabela 5. Results of the Western blot test aimed to detect the presence of anti-Borrelia antibodies among forest service employees - elimination of infection with maintenance of symptoms and subsequent infection including EM in the history

\begin{tabular}{|c|c|c|c|c|c|c|c|c|c|c|}
\hline \multirow[b]{2}{*}{$\begin{array}{l}\text { Number } \\
\text { of } \\
\text { patients }\end{array}$} & \multicolumn{5}{|c|}{2009} & \multicolumn{5}{|c|}{2012} \\
\hline & $\begin{array}{l}\mathrm{Wb} \\
\mathrm{IgM}\end{array}$ & $\begin{array}{l}\mathrm{Wb} \\
\mathrm{IgG}\end{array}$ & $\begin{array}{l}\text { Antigens } \\
\text { from in vivo } \\
\text { group }\end{array}$ & Symptoms & Treatment & $\begin{array}{l}\mathrm{Wb} \\
\mathrm{IgM}\end{array}$ & $\begin{array}{l}\mathrm{Wb} \\
\mathrm{IgG}\end{array}$ & $\begin{array}{c}\text { Antigens } \\
\text { from in vivo } \\
\text { group }\end{array}$ & Symptoms & Treatment \\
\hline $1(2 \%)$ & - & + & VlsE & $\begin{array}{c}\text { osteoarticular } \\
\text { pains } \\
\text { myalgia }\end{array}$ & + & $\begin{array}{r}\mathrm{nc} \\
\text { burgc }\end{array}$ & orferi & $\begin{array}{l}\text { orrelia } \\
\text { antibodies }\end{array}$ & $\begin{array}{c}\text { EM } \\
\text { osteoarti- } \\
\text { cularpains } \\
\text { myalgia }\end{array}$ & + \\
\hline
\end{tabular}

In $17 \%$ of foresters in tests conducted with an interval of 3 years, there existed only IgM anti-OspC Borrelia (Table 6). They informed about existence of clinical symptoms and treatment used. Probably it can be presumed that kind of serological status is associated with existence of Borrelia infection in 2009, which was eliminated. However, in 2012, was a re-infection with B. burgdorferi. Foresters are still exposed to multiple bites by ticks, so one cannot rule out the existence of occurring infections.

Table 6. The results of Western blot test for the presence of anti-Borrelia antibodies in forest service workers - only the presence of OspC anti-Borrelia burgdorferi

\begin{tabular}{|c|c|c|c|c|c|c|c|c|c|c|}
\hline \multirow[b]{2}{*}{$\begin{array}{c}\text { Number } \\
\text { of } \\
\text { people }\end{array}$} & \multicolumn{5}{|c|}{2009} & \multicolumn{5}{|c|}{2012} \\
\hline & $\begin{array}{l}\text { Wb } \\
\text { IgM }\end{array}$ & $\begin{array}{l}\text { Wb } \\
\text { IgG }\end{array}$ & $\begin{array}{l}\text { Antigens } \\
\text { from } \\
\text { in vivo } \\
\text { group } \\
\end{array}$ & Symptoms & Treatment & $\begin{array}{l}\text { Wb } \\
\text { IgM }\end{array}$ & $\begin{array}{l}\text { Wb } \\
\text { IgG }\end{array}$ & $\begin{array}{l}\text { Antigens } \\
\text { from } \\
\text { in vivo } \\
\text { group }\end{array}$ & Symptoms & Treatment \\
\hline $\begin{array}{c}3 \\
(17 \%)\end{array}$ & $\begin{array}{c}\text { OspC anti- } \\
\text { B. afzelii } \\
\text { B. garinii } \\
\text { B.burgdorferi } \\
\text { S.s. } \\
\text { B. spielmanii }\end{array}$ & - & - & $\begin{array}{l}\text { headaches } \\
\text { osteoarthritis } \\
\text { muscle pain }\end{array}$ & + & $\begin{array}{c}\text { OspC anti- } \\
\text { B. afzelii } \\
\text { B. garinii } \\
\text { B.burgdorferi } \\
\text { S.s. } \\
\text { B. spielmanii }\end{array}$ & - & - & $\begin{array}{l}\text { headaches, } \\
\text { osteoarthritis } \\
\text { muscle pain }\end{array}$ & + \\
\hline
\end{tabular}

In 15 foresters (36\%) treated by antibiotics had still strongly expressed immune response occurred as IgM/ IgG anti-Borrelia (Table 7). During 2009 - 2012 period they were repeatedly stinging by ticks and they declared symptoms of osteoarthritis, muscle pain, and headache. In 7 out of 15 foresters (47\%) there was persistence of response against the same antigens from in vivo group (grey boxes in Table 7). In case of the next 7 people in this subgroup (47\%) there was some dynamics: the disappearance or appearance of IgG to specific antigens from in vivo group. It showed us that the process of immunostimulation is active, time-varying and possibly associated with Borrelia strategies (black boxes in Table 7). We observed different frequencies- disappearance of IgG to specific proteins BBA36, BB0323, CRASP3 and pG in 4 of 15 patients (27\%). In 3 people (20\%) there was appearance of IgG antibodies for the same in vivo antigens. The only exception was IgG anti-VlsE antibodies. It was consistently reported in all of subgroup (15 people) infected with $B$. burgdorferi. 
Table 7. The results of Western blot test for the presence of anti-Borrelia antibodies in forest service workers - the dynamics of appearance and disappearance of IgG antibodies to Borrelia antigens from the in vivo group

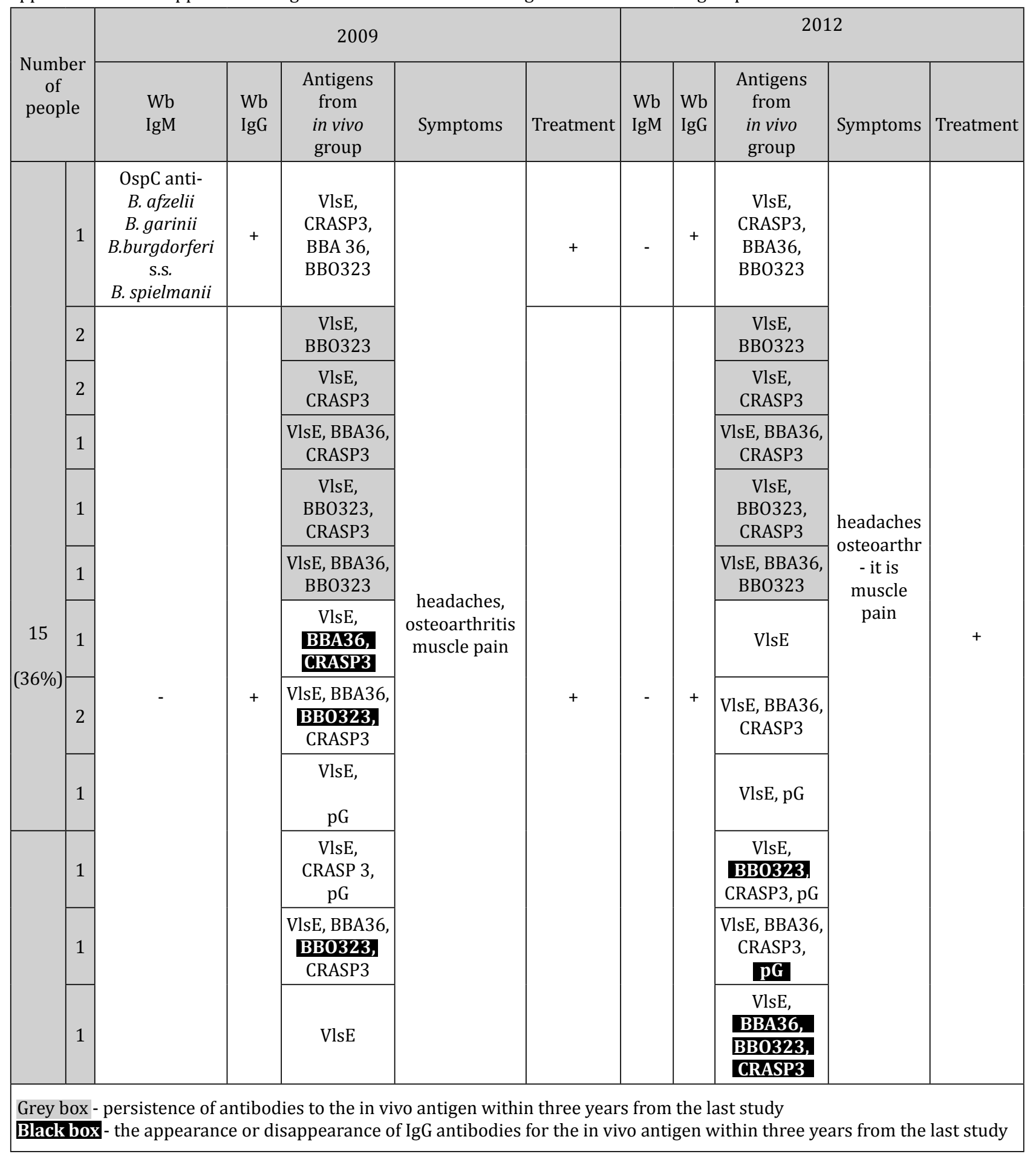

\section{Discussion}

The immune response to infection with $B$. burgdorferi occurs in a diverse and individual pace. It should be taken into consideration while estimating the clinical and serological status of each patient. Clinical symptoms of Lyme disease may not be eliminated despite the implemented treatment. Simultaneously there may be strongly expressed stimulation of the production of IgG anti-Borrelia antibodies. The presence of IgG antibodies to the in vivo antigen indicates their importance in the late response to infection with Borrelia. Appearance and disappearance of antibodies to in vivo proteins shows continued availability of bacterial antigens to the host organism and long-term immune stimulation. 
In vivo proteins, in addition to VlsE and DbpA, are not usually used in the serological diagnosis, even though many researchers notice high diagnostic potential (Aguero - Rosenfeld et al. 2005, Hofmann et al., 2006, Zajkowska et al., 2006, Bykowski et al., 2008). The tests carried by Hofmann et al. showed that late Borrelia infection is characterized by presence of IgG anty-BBA36, BB0323, CRASP3, pG. In patients with Lyme arthritis there were antibodies to BB0323 (90\%), BBA36 ( $67 \%$ ), p83 ( $71 \%$ ) (Hofmann et al., 2006). In their own studies, in patients repeatedly stabbed by ticks, with clinical manifestations of Lyme arthritis, there were also antibodies for BBA36, BBO323, CRASP3 and pG (Tokarska - Rodak et al., 2008, Tokarska - Rodak et al., 2010). The percentage of positive results for IgG anti- BBK323 antibodies increases in persistent infections as neuroborreliosis and arthritis (Aberer 2007 Tokarska - Rodak et al., 2010). Anti Borrelia antibodies can persist despite implemented treatment. In patients with clinical manifestations of Lyme disease observed them both before the implementation of antibiotic therapy, after antibiotic therapy, and for 6 weeks after the end of treatment (Tokarska - Rodak et al. 2010). IgG antibodies to Borrelia antigens, including ones expressed in vivo, may exist consistently even for 3 years but they may also be characterized by certain dynamics. This indicates how dynamic the process of Borrelia burgdorferi infection is, and demonstrates that the process of immunostimulation is active and time-varying. Possibly that this process is associated with the Borrelia strategies, among other things by the expression of CRASPs proteins and their role in the binding of complement regulation factors (Singh et al. 2004, von Lackum et al. 2005, van Burgel et al. 2010, Siegel et al., 2011).

Foresters are exposed to multiple bites by ticks, so we cannot eliminate existence repetitive infections. In $17 \%$ foresters, who underwent examination with an interval of 3 years (2009 and 2012), in both tests there were IgM anti-OspC, at the same time with the absence of IgG antibodies. IgM anti-OspC antibodies are highly acclaimed in the diagnosis of Lyme disease, and their presence in the absence of IgG antibodies signalizes an early response to infection process (Chmielewska-Badora et al., 2006, Hofmann et al., 2006, Zajkowska et al., 2006). Therefore, it is right to perform the annual diagnostic tests for Lyme disease in groups that are exposed to infection with B. burgdorferi on the grounds of their occupation. Anti-Borrelia antibodies can be possibly persistent, despite previous treatment and elimination of the symptoms of the infection. Nevertheless presence of Borrelia antibodies in the absence of clinical symptoms is not an indication, for the implementation of antibiotic therapy, according to guidelines (Wilske et al., 2007, EUCALB 2008, CDC 2011).

The treatment used in Lyme disease may be effective and lead to the total elimination disease symptoms, and disappearance of specific antibodies. In some cases, despite of antibodies elimination there is no symptoms reduction of Lyme diseases. It may suggest existence of post- treatment Lyme disease syndrome (PTLDS). The PTLDS can be signalized if symptoms associated with Borrelia infection are persistent, and last longer than 6 months after treatment. According to the guidelines, this condition does not justify the use of antibiotics, which is referred as useless and potentially harmful to the patient with PTLDS (Lakos, 2012, CDC, 2011). Then the medical and laboratory activities should be focused on assessing the effectiveness of treatment, exclusion of possible failure of therapy or taking into account other factor which is not related to Borrelia infection (Lakos, 2012, CDC, 2011). The cause of PTLDS is not completely clear. It is assumed that these symptoms may be related to the elements of tissue damage or dysfunction of the immune system during the infection. Similar complications including autoimmune reactions may occur in other infectious diseases (CDC, 2011). Long-standing persistence of symptoms that may be associated with PTLDS is an important and strongly noticed problem of both doctors and physiotherapists.

The obtained results indicate the advisability of annual tests for Borrelia infection for people working in conditions predisposing to infection. Unfortunately, in the vast majority of forest districts, the employer finances only the first stage of diagnosis (ELISA tests). Confirming tests (Wb) employees found on their own.

In practice it means that many people who are advised to do a confirmation test do not do such tests. At the moment there is no legislation which would impose an obligation on employers to perform a full, two-stage diagnosis in the direction of Lyme disease.

\section{Conclusions}

Analysis of appearance and disappearance antibodies to Borrelia antigens expressed in vivo showed, how active, long and time-varying process is this infection. This forces an individual approach to each patient, in whom there is a suspicion of Lyme disease. What is more it imposes a need to consider often ambiguous serological results with clinical manifestations of infection. Especially it is important for people exposed to Borrelia infection on the grounds of their occupation.

The expression of individual proteins of spirochetes and their exceptionally high immunogenicity make diagnostic procedure effective. It is postulated that the use of a wider range of antigens B. burgdorferi from in vivo group: BBA36, BB0323, CRASP3 and pG in Western blot diagnostic tests could help to increase diagnostic accuracy in difficult and ambiguous cases of B. burgdorferi infection. 


\section{References:}

1. Aberer E. (2007), Lyme borreliosis - an update. Journal der Deutschen Dermatologischen Gesellschsft, 5, 5, s. 406-413.

2. Aguero-Rosenfeld M.E., Wang G., Schwarz I., Womser G.P. (2005), Diagnosis of Lyme borreliosis. Clin.Microbiol. Rev. 18, 3, s. 484-509.

3. Bárcena-Uribarri I., Tein M., Bonde M. (2012), Porins in the Genus Borrelia. W: A. Karami (red.), Lyme disease. INTECH, s. 139-160.

4. Bykowski T., Woodman M.E., Cooley A.E. (2008), Borrelia burgdorferi complement regulator-acquiring surface proteins (BbCRASPs): Expression patterns during the mammal-tick infection cycle. I.J.M.M. 298, Supl 1, s. $249-256$.

5. Chmielewska-Badora J., Cisak E., Wójcik-Fatla A., Zwoliński J., Buczek A., Dutkiewicz J. (2006), Correlation of tests detection of Borrelia burgdorferi sensu lato infection in patients with diagnosed borreliosis. Ann. Agric. Environ. Med. 2006, 13, s. 307-311.

6. Hofmann H., Wallach R., Lorenz I., Bechtel, M. (2006), Comparison of a New line assay using purified and recombinant antigens with a European lysate blot for serodiagnosis of Lyme borreliosis. I.J.M.M. 296, s. $288-290$.

7. Lakos A., Igari E. (2012), Advancement in Borrelia burgdorferi antibody testing: Ccomparative Immunoblot Assay (COMPASS). W: A. Karami (red.), Lyme disease. INTECH, s. 55-78.

8. Singh S. K., Girschick H. J. (2004), Molecular survival strategies of the Lyme disease spirochete Borrelia burgdorferi. Lancet Inf Dis, 4, s. 4575-83

9. Tokarska-Rodak M., Fota-Markowska H., Śmiechowicz F., Gajownik, B., Prokop, M., Modrzewska, R., KoziołMontewka, M. (2010), Antibodies against in vivo B. burgdorferi antigens evaluated in patients with Lyme arthritis with reference to treatment. Adv. Clin. Exp. Med. 19, 4, s. 489-496.

10. Tokarska-Rodak M., Kozioł-Montewka M., Fota-Markowska H., Bielec, D., Modrzewska, R., Pańczuk, A. (2008), Frequency and specificity of the antibodies against Borrelia burgdorferi tested by Western blot method in patients with symptoms of arthritis. Cent. Eur. J. Immunol. 33, 4, s. 220-223.

11. Von Lackum K., Miller J.C., Bykowski T. (2005), Borrelia burgdorferi regulates expression of Complement RegulatorAcquiring Surface Protein 1 during the mammal-tick infection cycle. Infect. Immun. 73, 11, s. 7398-7405.

12. Wilske B., Fingerle V., Schulze-Spechtel U. (2007), Microbiological and serological diagnosis of Lyme borreliosis. FEMS Immunol. Med. Microbiol. 49, s. 13-21.

13. Zajkowska J., Kondrusik M., Pancewicz S.A., Sienkiewicz, I., Grygorczuk S. Wierzbińska R., HermanowskaSzpakowicz T. (2006), Laboratory diagnosis of Early Lyme borreliosis - comparison of ELISA, Western blot (EcoLine), and PCR results. I. J Med. Microbiol. 296, s. 291-293.

14. Zajkowska J., Kondrusik M., Pancewicz S., Grygorczuk S., Wierzbińska R., Hermanowska-Szpakowicz T., Czeczuga A., Sienkiewicz I. (2006), Test Western blot z białkiem VlsE oraz antygenami „in vivo” $w$ diagnostyce boreliozy z Lyme. Przegl. Epidemiol. 60, s. 177-185.

\section{Websites}

1. Van Burgel N., Kraiczy P., Schuijt T., Zipfel P.F., van Dam A.P. (2010), Identification and functional characterization of Complement Regulator Acquiring Surface Protein -1 of serum resistant Borrelia garinii OspA serotype 4. BMC Mikrobiol. 10.43. <http://www.ncbi.nlm.nih.gov/pmc/articles/PMC2833144/>, (10 lipca 2013). Cytowanie w tekście (van Burgel, 2010)

2. European Concerted Action on Lyme Borreliosis (2008), http://meduni09.edis.at/eucalb/cms/index. php?option=com_content\&task=view\&id=38\&Itemid=102, (20 lipca 2011). Cytowanie w tekście (EUCALB, 2008)

3. Coburn J., Leong J., Chaconas G. (2013), Illuminating the roles of the Borrelia burgdorferi adhesins.Trends.Microbiol. <http://www.cell.com/trends/microbiology//retrieve/pii/S0966842X13001145?_returnURL=http://linkinghub.elsevier.com/retrieve/pii/S0966842X13001145?showall=true>, (30 lipca 2013).

Cytowanie w tekście (Coburg, 2013)

4. Siegel C., Hallström T., Skerka Ch., Eberhardt, H., Uzonyi, B., Beckhaus, T., Karas, M. (2010), Complement factor H-related proteins CFHR2 and CFHR5 represent novel ligands for the infection-associated CRASP proteins of Borrelia burgdorferi. <http://www.ncbi.nlm.nih.gov/pmc/articles/PMC2958145/?tool=pubmed>, (03 sierpień 2013). Cytowanie w tekście (Siegel, 2010)

5. Centers for Disease Control and Prevention. http://www.cdc.gov/lyme/, (14 września 2011). Cytowanie w tekście (CDC, 2011) 